\title{
Personhood of Water
}

\section{Depositions of Bodies and Things in Water Contexts as a Way of Observing Agential Relationships}

\section{Christina Fredengren}

\begin{abstract}
This paper stems from a curiosity about relationships between water, depositions, life, death and sacrifice. It probes into how traditional binaries such as nature/culture, human/ animal, alive/dead and language/reality were addressed in Irish medieval place lore, using critical posthumanist theory to explore ways in which agential powers were not merely ascribed to the environment, but also observed and acknowledged by people in the past. It also considers how the agentialities of both artefacts and waters could have affected and made their way into human storytelling. In so doing, the paper presents a contribution from archaeology to the emerging field of environmental humanities, offering research that could entice us to sharpen our environmental sensibilities and respond to environmental change. Depositions of things and bodies in wet contexts are often understood as sacrifices made to deities located in the otherworld. However, there is plentiful evidence in archaeology and in medieval place-lore to suggest that waters were observed as being alive, as immanent beings, as more-than-human persons who could have received these depositions as gifts. This study explores how depositions would have added to and reconfigured such waterpersonhood in locally and regionally situated ways, and how they may also have worked as apparatuses for paying close attention to the water environment.
\end{abstract}

Keywords: materiality, rivers, lakes, wetlands, ontology, human-animal relations, sacrifice, gender, more-than-human agency, environmental humanities

Archaeological Research Laboratory, Department of Archaeology and Classical Studies, Stockholm University Email: christina.fredengren@arklab.su.se 


\section{Introduction}

Many of today's environmental problems are connected to the separation of nature from culture, which has left nature as 'the inert ground for the exploits of Man' (Alaimo \& Hekman 2008:4) or as a blank or dead space onto which humans project their meaning. Such thinking and practices are also linked to the misrecognition and oppression of a range of naturalized human and non-human others (Alaimo \& Hekman 2008:4). New scholarship in the environmental humanities (see Rose et al. 20I2) is inspired by critical posthumanist feminisms that challenge a range of dualisms, such as those of nature/culture, human/animal, mind/matter, life/death or the linkages between language and reality (see Haraway 2008; Barad 20I2; Braidotti 20I3). This research has inspired the field of environmental humanities and highlighted how important it is to question anthropocentric perspectives to include a range of excluded others, the more-than-human, in the academic analysis. Here, for example, Ghosh (2016) argues for acknowledging how a range of 'othered' humans, things, animals and the environment contribute with their own agencies to the development of relations and storytelling.

Whereas personhood in archaeology has most often been conceived as that of humans and connected with the ongoing separation between the individual and the world (Fowler 2004:8), this paper connects with current discussions on how watery places may have been acknowledged as persons. One example of this can be found in Maori lore, which captures waters as living agents (see Hikuroa 20I7). In fact, this lore holds that New Zealand's Whanganui River with its wetlands, streams, tributaries and lakes are an 'indivisible and living whole' with personhood, which in turn has entitled it to legal rights (Ruru 20I8). Hikuroa (2017) argues that Maori indigenous knowledge about rivers is based on techniques that are on par with scientific observation methods. While the implications of giving legal rights to animals or rivers or the challenges involved in efforts to speak for nature (Braidotti 20I3:76-8I and references therein) are important topics that could be explored further, this paper concentrates on how archaeology and written sources from the past can be used to gain knowledge of similar ontologies and ways of engaging with the environment, which may have been present also in north-western Europe.

The cult of river (or lake) goddesses in Britain, Ireland and France as evidenced in place-names and archaeology, as well as the importance of the severed head and its relationship to waters, are well-known themes in classical texts and in early Irish literature in particular (Ross I996 [1967]:46-48). These sources provide aspects on the birth, character, agencies and names of waters, but may also be read from a different perspective to show how they deal with depositions, that is, the placing of objects or body parts in 
waters and their discovery. The practice of depositing valuables in water is well attested in large parts of northern and western Europe and is evident in the long-term archaeological record, from at least the Neolithic into historic times (Bradley I990, 20I7:4, figure I; Fontijn 2003). For example, in Mälaren region of central Sweden, swords and twisted neck-rings were deposited in water contexts during both the Late Bronze Age and Early Iron Age (Fredengren 20II), and the depositions of human and animal bodies in watery places may have continued into the medieval period (Fredengren 20I5). Such depositions are often seen as sacrifices to gods, goddesses or spirits, and as facilitating communication with the supernatural and the world beyond, or are interpreted as artefact dumping, taking excess materials out of circulation and therefore play a role in the socioeconomic system (see Bradley 20I7, chapter 8 and references). Bradley (20I7:I45-I46) mentions that European written sources suggest three different reasons for the deposition of objects: that they were stored for later use; that they had special powers and needed to be taken out of circulation so not to become private possessions; they were gifted to the otherworld (as in spirits or deities); or, they were to be used in life after death. Some of these interpretations resonate with stories such as those in the Volsunga Saga, Niebelungenlied and Egil's Saga (Bradley 20I7:I45-I46). I would like to add to this discussion, inspired by Hikuroa (20I7), by testing an additional hypothesis; namely, that the practice of depositing may be connected with an acknowledgement that these watery environments were alive with personhood, and that these deposited 'things', such as neck-rings or swords, in fact contributed towards the extension of such personhood, and were directed at watery more-than-human persons or perhaps deities, but as such, more immanently present in this world. I therefore shift the interpretation from mainly dealing with the deposition of the artefacts themselves or the landscape and places, towards an examination of how the water was understood and recognized. Shedding light on this phenomenon is the task of the research presented here.

Of particular importance to the current paper are mainly medieval Irish written sources, especially those which offer 'place-lore', or tales of how topographical features acquired their names, and which will be detailed below. Working from these, Muhr (1999) has linked incantations on water to poetic knowledge, while Hopkins (I992) has engaged with the symbology of water in early Irish writing, and Waddell (20I4) has eloquently acknowledged the connection between these medieval place-lore poems of, for example, the Boyne River, archaeology and artefact depositions. It is clear that lakes and rivers, as otherworldly locations, had a particular importance in the place-lore of early and later medieval Ireland (see for example Carey 2000[1983]) and would also be common in later times 
(see Fredengren 20I6). An additional motivation for this paper is to bring these written sources to the attention of a Scandinavian audience. As will be shown, there is ample evidence in the literary sources to suggest that waters, human remains and artefacts were observed as alive and imbued with the powers of agency, and that they were important allies in various political and religious events.

The relationship between nature/culture and various species, as well as that between things, materiality and meaning, has been highlighted recently in the writings of Haraway (2008, 2016) and Barad (2007, 20I2). Barad (2007:90) argues that the world comes into being through constantly changing relationships and entanglements between meaning and matter. Thus, Barad takes the so-called ontological turn one step further by discussing how apparatuses/observation practices (scientific, theoretical or other) bring the world into existence as situated entanglements between ethics, ontologies and epistemologies. Here human and non-human actors co-constitute the world in an intra-active way. Furthermore, Braidotti (20I3:60-6I) and Bennett (20IO:IO-II) have troubled the boundary between life and death and focused on how matter, which has been understood as dead and inert, may be explored as alive: that is, generative and capable of actions. What they allude to is the idea that self-organising matter forms transversal connections across material, species and gender boundaries and lets new properties emerge. Whereas many materializing realties are coshaped by human and more-than-human agencies, the world abounds with connections and relations, many of which escapes human capture alone. However, occasionally this exuberance can be sensed as hauntings or the effects of enchantment (see Fredengren 20I6) or, as exposed in this paper, as living presences in the water landscape, that may be captured as if the waters had a personality. These insights are important for the shaping of an 'ecological sensibility' that may be enticed to the forefront by not drawing too sharp a boundary between living and non-living things (Bennett 20IO:IO). It follows that archaeological material, as well as the watery environment, may need to be acknowledged as having had the capacity to act and be active in the formation of transversal alliances; at the same time, it was also accepted as alive during certain periods in the past.

This paper explores how medieval place-lore - if taken as ontologies, that is, insights into how the world exists and comes into being (see Holbraad \& Pedersen 2017) - captures waters as agential. Further, it investigates how depositions of artefacts and body parts may have been a means to interact with such agents, and how they may have been interlaced with and expanded the personae of waters, and also to some extent could have worked as tools with which to observe the world. The paper discusses agency as distributed among many parties, that is to say, how the water as 
an inorganic compound, together with that of archaeological depositions of artefacts and body parts, may have contributed to the ongoing formation of these agencies. So, instead of understanding this place-lore and those depositions as a way that people ascribed meaning onto the landscape, they could instead be used to gain insights into how people observed, interacted with and were affected by more-than-human agencies, and with these forces contributed to the shaping of particular qualities of the world, with both ethical and material consequences.

The specific aim is to explore whether there are reasons to believe that various waterways in north-western Europe were observed as alive in the past (with a particular emphasis on late prehistoric and medieval times) and to investigate what roles various depositions in the wet environment may have played in this. The goal is to feed into a wider discussion in the environmental humanities on the personhood of waters in the Western world, drawing on contributions from archaeology, but also to reflect on the morethan-human agentialities at work in human storytelling.

This raises a range of questions to be dealt with in this article, such as: What do primarily medieval Irish written sources on place-lore tell us about the lively and agential capacities of the watery environment? Further, do they inform us of other ways of drawing the boundary between nature and culture, life and death, language and reality? Is there evidence to suggest that the water was acknowledged as being alive?

Can depositions of artefacts and body parts be used as ways of observing the world (or even tools to observe the world) and interacting with it, in ways that also intra-actively shaped the world (that is, would they work as Baradian apparatuses), and does this give us an entrance for discussing the personhood of rivers in the context of north-western Europe in the past?

\section{Storytelling, material agency and ontologies}

This paper deals mainly with Dindshenchas - the lore of notable places in Gwynn's editions (Gwynn ed. I99I[I906], I99I[I9I3]). They provide explanations for how important topographical features and places, such as hills, lakes and rivers in Ireland got their names (see also eDIL: Electronic Dictionary of the Irish Language nd.). The Dindshenchas derive from a large number of verse and prose manuscripts and the earliest parts of the collection are generally seen to have originated in the eleventh or twelfth centuries AD (such as the Book of Leinster), while other parts were composed in the eighteenth century. Both the dating and the internal relationships between these texts are complex and much debated (see Thurneysen I92 I; Ó Concheanainn I98I; Downey 20I0; Theuerkauf 2017:49-50). Ad- 
ditionally, some other sources are also used in the paper, such as Tírechan's description of St Patrick's travels through Ireland (Bieler ed. I979), as a section deals with depositions of artefacts at a well, taking us further back in time as the text dates to the seventh century $\mathrm{AD}$, but reference is also made to a selection of classical sources. In this paper, I, as an archaeologist, will to a certain extent be dependent on secondary texts, and not be able to go into the exact wording, or various recensions and genealogies of the Irish texts. Instead, I will open up a new way of reading them, that is, in conjunction with and through a variety of materialities, where both waters and various items deposited in waters may have made a difference to the development of these texts.

The challenge of how to use written sources and archaeology has been dealt with by numerous scholars (e.g. Hedeager 20II; Price 20IO; Lund 20IO, 20I7; Downey 20IO; Waddell 20I4). In her study of the relationship between Norse myths and archaeological materiality, Hedeager (20I I:Xxvixxix) argued that post-processual approaches initiated a reformulation of the relationship between these two source materials. She found that comparisons with archaeological material can revitalize texts (Hedeager 20II), and that they facilitate a more symmetrical approach between the fields of history and archaeology. Price (2OIO) has likewise argued that selecting and placing objects in Norse Viking-Age burials may have worked as a kind of mortuary theatre, where the use of material narratives would have passed the dead and their things into the world of storytelling, which eventually resulted in what could be termed Norse mythology. Waddell (20I4:xii) reminds us of the risks, but also the benefits, of straying out of our own archaeological expertise in order to have encounters with the written text evidence, where 'archaeology may illuminate some aspects of myth'. Hence, archaeology and texts can co-work to expand the complex interlinkages between historiography, myth and lived reality by adding the materialities of archaeology. Downey (2010), however, points to the challenges of using medieval literary sources, like those associated with monuments such as Tech Midchúarta at Tara in Ireland, since, while addressing archaeological sites of earlier periods, they may misinterpret the use of these sites in earlier periods (in this case a cursus monument was vividly described as a banqueting hall in medieval times) while using them in their cultural history writing. Nonetheless, it can be argued that these enigmatic sites exerted material agency on medieval storytelling, as they inspire and interfere with storytelling, while the direction the tales took is not always clear.

Furthermore, that artefacts have been interpreted as agential in the past has been discussed by many researchers. Most relevant for this work, Lund (20I0, 20I7) addresses how various depositions at the water's edge, such as those of Viking Age artefacts, could have been perceived by people as ani- 
mate. Here, I take these approaches one step further to investigate the role in spatially situated storytelling, and argue that sometimes archaeological materials and the water element were not only ascribed the meanings of being animate, but also observed, as such, and that they thereby were a part not only of an epistemology, but also of ontologies that reveal and affect the ways the world exists and comes into being. Hence, it is about letting in more-than-human agencies of the watery environment and the artefacts into the analysis, and taking their agentialites more seriously. In this paper, I expand upon my earlier interests in the agential powers of waters, where post-glacial land rise and the following alteration of the fluid landscape also may have changed depositional patterns (Fredengren 20II, 20I5), and also include an exploration of agencies of things and body parts. This resonates with how Bennett (2010:4-6) has underlined the importance of thingpower, 'the curious ability of inanimate things to animate, to act, to produce effects dramatic and subtle', where humans and non-humans as well as things need to be recognized as 'vital players in the world'. This 'thingpower' emanates from the fact that material entities are more than what is captured contextually and semantically by humans (Bennett 20I0:5) and that they exercise excessive agentialities beyond human control. Whereas (for example, as Price 2010 suggests) the archaeological material may tell of material practices which were eventually documented in narratives and myths, there is more to the encounter with both artefacts and the water environment. What I add now is how the material remains work together with the environment, and how they in alliance could have affected, influenced and infiltrated storytelling in later periods as well, but also changed and challenged such narratives through their own vibrant, agentic and transformative capacities, which are often more than what is captured in storytelling and language alone.

\section{Alive inside}

There is substantial written material, both in classical sources, such as Posidonius and Strabo, and in early Irish Literature, that is relevant to the discussion of waters as sacred- and living entities (Ross 1996[1967]:46-48). Some of this literature is connected with depositions of both artefacts and bodies in the water element. For example, Strabo draws on Greek myths, where rivers, such as the Aechelous, were gods (Leonard Jones 1923:5758 , Book X). Based on Posidonius, Strabo writes further about the Celts, who used sacred lakes (a particular lake near Toulouse is mentioned) for the deposition of treasures. These treasures were described as having been of gold and silver, depositions for the divine, which people saw as untouch- 
able (Leonard Jones I923:207, Book IV, chapter I, verse I3, see also Ross I996[I967]:46-48).

Ross (I996[1967]:46-48) writes of the importance of rivers and wells as a focus for ritual practices. As Hopkins (I992:82) observes, the river was a place seen to mediate between life and death. Rivers in many places in Europe were associated with mother goddesses and fertility due to their lifegiving as well as destructive powers (Ross I996[I967]:46-48). Place-name evidence can be found on the continent as well as in Britain and Ireland. For example, the river Marne is named after the Gaulish Matrona, the river Seine after Sequana, the goddess of its source (Ross I996[I967]:46-48; see also Holder i905).

Doherty (2005:6-7) has argued that while Christianization often separated beliefs connected with nature from those connected with culture, this was not the case in Ireland. Instead the energy of nature was expressed in the continued veneration of, for example, holy wells and trees. In Ireland the river Boyne is named after Boand and the Shannon after Sinann (Ross I996[I967]:47). The river Inny is named after Eithne, who while pregnant drowned in the river, and her child was taken out of her side, as a caesarean section (Stokes I892:477). The naming of waters in these sources is on many occasions connected to deaths and drownings, marking lakes and rivers as commemorative spaces.

Moreover, there is more information around the river and lake placelore than that which reflects the human naming of the water. There is lore of the kind that recognizes artefacts and practices that constitute a part of the archaeological material.

One example is the poem of Loch Séta in the Dindshenchas (Gwynn ed. I99I[1906]:226-227):

I. Here was sunk that ancient treasure, the diadem of Loegaire Lorc of the Leinstermen, when maidens put it there, the daughters of spruce Faindle.

2. Dub-Da-Roth's son, bold warrior, met his death in payment for it: treasure and werewolf man, here alike they lie.

3. Moncha, Dina, Dalb, dumb Echen and Biblu, as was met, he encountered them all five, together with their father, here.

The poem mentions how the diadem of Loegaire Lorc was sunk in Loch Séta by maidens, and how a werewolf man (a shape-shifter) had to pay for the deposition with his life, and may also have been placed in the water with the treasure. We are told that the treasure, which may have been the regalia of Loegaire, was old when it was deposited and therefore may have been in circulation for a while. It is also said that the treasure was placed in the water by five maiden sisters, and that their well-dressed father attended 
the event. In this sense the ritual was a family affair, but it may have had a bearing on regal/dynastic affiliations as much of this literature is deeply entwined with the exercise of power. This may in fact be understood as a description of a sacrifice and the depositions of both body and artefact in waters. While the poem describes both human agency and encounter with a more-than-human creature (as in the werewolf man), it does not inform us on the agential powers of the water, aside from providing information on some of the element's affordances, as a space where treasures could be placed. We have to turn to other places to find such information on what agencies the combination of artefacts and water brings into being.

\section{Segais the well of wisdom}

In the early Irish sources, the otherworld was seen as located under the sea or a lake, on islands, off the coast or under hills. It could be accessed through underwater or underground passages that lead to this world of plenty (Carey 2000[I983]:I I6-I I7). In Immaccallam in dá Thuarad-The Colloquy of the Two Sages (translated by Stokes I905 and contained mainly in the Book of Leinster compiled around AD II60) - a young man Néde, who was to learn the art of poetry, went to the edge of water, as that was a place for the revelation of knowledge. At the water he heard a chant, which he understood by casting a spell on it, and the water cried out that someone else had taken up Néde's father's position as chief poet of Ireland (Stokes I905; Muhr I999:196-I97). In early Irish literature water words were used as metaphors for knowledge (Muhr I999:196). This is exemplified by Muhr with reference to the use of the words sruth fáil, sruth buais, which could be translated into 'stream of knowledge' and 'the estuary of wisdom' indber $n$-ecnai, and the source of rivers or their banks were places where poets could access a particular type of inspiration. Based on the literary sources Muhr (I999:I96) suggests that rivers were often seen as supernatural beings in early Ireland, and otherworld wisdom could be accessed through water. To this could be added the term éicse (eDIL: Electronic Dictionary of the Irish Language nd.), while central in these texts are also links to revelations as in the wisdom of divination, such as a calling to poetry writing, which is related to the term (do)-écci, which may mean to be a seer. Hence, a particular type of knowledge could be attained by paying close attention to waters, and those thinking through water may possibly achieve particular foresight and ways of sensing the world.

As described in the Dindshenchas (Gwynn ed. I99I[I9I3]:27, 287, 293), the source of wisdom was a well, Segais or Condla's well, located in the otherworld. Seven otherworldly streams flowed into it and seven streams 
flowed out of it. Around Segais were hazel-trees that dropped nuts into the waters (see also The Cauldron of Poesy (Breatnach 1981:67)), which created bubbles of inspiration that spread to the sources of rivers in the world of the living. Even the hazelnuts could make their way to the land of the mortals, who could crack them open and gain divine wisdom, the nuts transforming them into seers. The wisdom could also be gained through eating a salmon that had consumed one of these nuts (Gwynn ed. I99I[19I3]:293-297). The otherworldly waters of Segais were seen to have many connections in the world of the living and to flow from the river Bann to the Severn, the Tiber and even Jordan and Euphrates, and then to paradise. From paradise the water would pass in a cyclical flow back to Segais (Gwynn ed. I99I[I9I3]:2733,35 ). Hogan (I9IO) has suggested that Segais would have been associated with the sources of the River Boyne, as located around Carbury Hill, and also pointed out that Segais could be associated with the Curlew mountains in the upper parts of the Shannon at the Boyle River. Then, as an otherworldly place, Segais may not have been connected with one fixed geographical location, but it could have been accessed at many different points in the landscape, and just as rivers, it has not only one, but many sources.

Not only did water provide inspiration, there are also other agential powers of waters that have been observed in this place-lore. In the Dindshenchas poem about the river Boyne (Boand I), Nechtain, one of the supernatural kings of Leinster, had a wife named Bóand (Gwynn ed. I99I[I9I3]:27-33, see also Theuerkauf 20I7). Bóand came to know of a secret well, Segais, guarded by her husband and three cupbearers. The well was known for its ability to burst the eyes of people that looked into its bottom, but she wanted to challenge its powers and approached the waters. This made the well burst with anger and it mutilated Bóand by sending three waves towards her. One damaged her eye, the other two her hand and foot. The waters then chased her all the way to the sea, where she died along with her dog Dabilla. One part of the river was called 'the Arm of Nuadu's wife and her leg' (Gwynn ed. I99I[I9I3]:27). This formed the river that was named Bóand after her (Gwynn ed. I99I[I9I3]:27-33), which is now the river Boyne, and the dog transformed into a rock at sea.

Likewise, the River Shannon got its name in a similar process. The poem Sinnan II reads:

A spring (not sluggish) under the pleasant sea

in the domain of Condla (it was fitting,

as we recount in telling the tale):-

to gaze upon it went Sinann

A well of lasting sorrow

Is by the edge of a chilly river 
(as men celebrate its fame),

Whence spring seven main streams.

Here thou findest the magic lore of Segais

With excellence, under the true spring:

Over the well of the mighty waters

Stands the poets' music-haunted hazel.

$[\ldots]$

Let us recount the entire journey

Whereon went Sinann of noble repute

To Lind Mna Feile in the west

With the choicest of her splendid equipment.

There lacks not any treasure we could desire

to the noble lady of the ...

save magic lore in its sequences:-

it was a wonted practice for her fresh life.

[...]

The woman of Luchar full of gentleness

Followed the stream of Segais

Till she reached the river's brink

and met destruction and utter frustration.

$[\ldots]$

There the comely lady was drowned

And perished under heavy injury;

Through the woman of warlike ardour is dead,

Her noble name clave to the river

$[\ldots]$

(Gwynn ed. I99I[I9I3]:289-29I)

Muhr (I999:200) notes that whereas Sinnan once may have been the guardian deity of the river, this duty may later have been taken over by the saint, Senán, and his monastery on the Shannon Estuary at Scattery Island. As Waddell (20I4, chapter 2) writes, the poems on the River Boyne provide a creation myth of a sacred river, much interlaced with the establishment of the megalithic structures at Newgrange, Knowth and Dowth. In addition to artefacts from the Mesolithic to the Iron Ages found on the shores and in the waters, there are also a significant number of depositions of human remains in the river and its lakes, for example in the Upper Shannon area, such as Lough Gara and the Boyle River (see Fredengren 2002). 


\section{The druid Cé and the rise of Lough Key}

Another poem on Lough Key, on the Boyle/Shannon Rivers, also bears witness to the co-joined agency between otherworld waters and dead/dying bodies that cause waters to rise in formerly dry grounds.

Loch Cé, - what was the cause of its breaking forth, when it was as yet a plain level and smooth?

the pure water, good sir, where is the spot whence it rose?

I ask you all, who was the Cé from whom everyone names the lake? to what ruler of famous Banba belonged the renowned druid who caused the lake to spread?

What was it that caused the growth of the green lake free from horror? the joyous bright pale water, tell me of its story!

The druid of Nuadu, heartener of the fray, son of Echtach, son of Etarlam, from his grave comes the name of the lake, when he came to it from the rout of a great battle.

From Mag Tured younder he came, when poisoned spears dealt wounds, smitten by keen-edged weapon; and he sat him down in the cairn of the mountain-peak.

Thereafter Cé arose from the cairn: he was all but stark-dead: emerging from his swooning weakness he went on to the middle if the smooth green plain.

There is a stone that thou hast seen in the plain: there was he laid under ground: when his stone was cast upon the cairn under the corpse rose up the mighty lake.

Hence comes the name Loch Cé:i declare it without deceit: from Nuadu's druid - splendid his valour is named the lake above all lakes

(Gwynn ed. 199I[19I3]:400-403) 
Here it is explained that the lake came into existence and acquired its name when erupting waters covered an area of land. The eruption was caused by the druid Cé lying down on a smooth plain, and then eventually dying. A cairn was set over him and the lake rose from under the corpse. While the poem may be a later explanation for the finding of underwater cairns and crannogs from the past (a number of these were exposed in connection with the draining of the nearby lake Lough Gara, and several crannogs have been recorded for Lough Key (see Fredengren 2002; National monuments Service nd.: RO०06-035/200/20I)). More importantly, it shows again how deaths and burials were connected with the outpouring of otherworldly waters. As Carey (2004) has explored, the plains under the lakes were also often given names in the literature. This suggests a continued memorialization of submerged and vanished lands.

The poem of another lake, Loch Riach, shows how water reacted when human heads were deposited in it. After a battle, the heads of the losers were placed in the well. This caused its water to spill out over its rim and land around it. Riach built a house over it and put a door over its mouth, but this was not enough to curb its evil powers and eventually it boiled over and drowned Riach and a large number of men. These men rotted in the lake water, which was subsequently coloured red (Gwynn ed. I99I[I9I3]:325329; Ross 1996[1967]:I43-I44).

There are further accounts of how human deaths and human heads were associated with the bursting out of waters. The tale of How Cormac mac Airt got his branch is a rather late example of this (O'Grady I 857:219). During a visit to the otherworld Cormac mac Airt came upon three huge wells at the end of a plain. Each of the wells had a head in it. The first well had a head with a stream flowing in through its mouth and two out of it; the second had a stream flowing into it and another out of it; and the third skull in the third well had three streams flowing into its mouth and one out of it. This further exemplifies the belief that the streams of the otherworld flowed through human skulls and into this world. The placing of human remains in waters can also be seen to bring out other reactions and characteristics of water. In the landscape poem of 'Sliab Gam' (Gwynn ed. I99I[19I3]:437; Ross I996 [I967]:I43-I44) it is mentioned how Gam's head was cut off at the edge of a spring and eventually thrown into its waters. The well reacted to this treatment by occasionally turning bitter. Also, the poem of Lough Cend (the lake of the heads) mentions how a battle between two heroes took place at this lake. The winner Cairpre threw nine hundred slain heads in its waters, and this made the water turn red (Gwynn ed. I99I[I906]:26I; Ross I996[I967]:I43-I44). Hence, these tales describe the waters not as mute recipients of depositions, but as entities which react strongly, and occasionally violently to what is being deposited in them. 


\section{Slán and healing waters}

There are a number of wells, lakes and rivers with variants of the name Slán, which can be understood as related to the word 'healthy' based on a translation of the place name (Joyce $1875: 83$ ), which again may be an aspect of their life-giving properties. Aitchison (I996:70) argues instead that the name would mean the fulfilment of a vow. One place often referred to in relation to depositions of human remains and artefacts in water is Bishop Tírechán's seventh-century account of St Patrick's visit to the well Slán in Findmag in Co. Mayo, which was used by druids for offerings and the water was honoured as a god. The well was marked by two rectangular stones, one placed at the well's mouth, where the water came out. According to the pagans, bones of a seer (Latin profeta) had been placed in a casket under this stone in order to bleach them and to save the seer from being consumed by fire. That the bones were placed in the well was the reason why it was worshipped as a god. This particular well was named 'the king of waters' (Bieler I979:I52-I55).

And he came to the well of Findmag, which is called Slán, because he had been told that the druids honoured the well and offered gifts to it as a god. [...] the infidels said that some wise man had made for himself a shrine in the water under the stone to bleach his bones perpetually because he feared the burning by fire; and they worshipped the well as a god. And Patrick was told the reason for its worship, [...] and said: 'It is not true what you say that it was the king of the waters' (for this is the name they gave the well: 'king of the waters'). And the druids and the pagans of that region and a very large crowd gathered together at the well and Patrick said to them: 'Lift the stone; let us see what is under it, whether bones or not, for I am telling you: under it there are not the bones of a man, but - so I believe - some gold and silver from your wicked sacrifices leaks through the cementing of the stones'. (Bieler I979:I52-I55)

Bieler (1979:258) placed this well in Athlone Barony in Co. Roscommon, while Hogan (I9I0:422) suggested it was in Carra Barony, Co. Mayo. The archaeological evidence from Inchagreenoge, Co. Limerick, describes how a male skull was found at the edge of a spring. The spring was surrounded by a stony platform and the skull was encased within natural limestone blocks (Grogan et al. 2007:I 47-I 49, 28I-284). The feature could be seen as a stone box set on a spring of water in which the skull was inserted, resembling the feature described in Tírechan. Particularly interesting is the fact that this skull was placed in a location where water bubbles rose from the underground and formed part of a larger stream that led onto the Shannon. The archaeological material here parallels the literary sources, which show the significance of placing human remains in locations where water broke 
out in the landscape, and that the union between human bones and water may have worked to divine the waters and to keep it flowing. However, the skull dates to the Bronze Age (Grogan et al. 2007:282) and not the Early Medieval period.

This provides further evidence of a tradition of worshipping waters that were with the deposition of human remains and treasures. Ironically, in this case St Patrick disproved the divinity of water by showing that there was no material evidence for the deposition of human remains in the well, thereby demonstrating the necessity for depositions of human remains for the existence of a divinity in the waters. It may also be of interest to note the value judgement expressed in the act of the seer's bones being placed in water to be bleached to save them from being consumed by fire. This could reflect the practice of cremation that may have been seen as an unsuitable handling of the bones for a person with prophetic capacities. Another possibility is that the waters worked to keep the individual alive in some respect, that is by transferring motion and restoring a kind of life to the bones. This may be important for understanding the bog-body phenomena. That is, wetlands may have been chosen for depositing bodies of seers, as this may have strengthened their life-forces, stretching their agentialites beyond individual death.

\section{Connections between eyes and water}

Just as involvement with water may expand human sensing, knowing the excesses of water was also acknowledged to have damaging effects. As mentioned above, the well of the River Boyne had the power to explode people's eyes when they were looking too deeply into its waters (Gwynn ed. I99I[I9I3]:27-33). There are other landscape poems about lakes and eyes, like Lough Dergderc, which got its name from a generous king who took out his eye and washed it in a well that afterwards coloured red. The king received two clear eyes in return (Gwynn ed. I99I[I9I3]:34I-345). There are parallels between the Irish stories and the Norse legend where Odin kept Mimir's head alive in a well to give him wisdom, but also left his own single eye in the well for the god to drink from these waters of wisdom (Ross I962, I996[I967]:I46-I56; Simpson I962).

There are Irish lakes named Lough Eyes or Lough na Súil - the lake of the eye (see Joyce I875:87-88). According to the story The Second battle of Mag Tuired, the evil Fomorian god Balor was killed as Lugh threw a slingshot through his only eye (Gray ed. I982:6I). According to local legend his eye was thrown into a lake, Lough na Súil, and burned a hole into the underground. This lake is located about $\mathrm{Ikm}$ to the north of the area of 
Moytirra (Mag Tuired), Co. Sligo. In fact, this is a lake which empties of water roughly every 25 years. A swirl in the mud with a dark hole in the middle where the waters are led to its underground sources can be seen those summers when the lake drains, and this is the place that was assumed to show the impact of the eye. It is also through this 'eye' in the lakebed that waters pour out to form the lake again.

Hopkins (I992:82) outlines the importance of such lake-bursts and emphasized that they may have been connected with the taking of the land, as waters provide lines in the landscape that often lend themselves as border markers. One example of this phenomenon, used by Hopkins, is from Lebor Gabála Érenn, the invasion myth of Ireland, where Cessair, daughter of Noah divided people into groups and they took various lands formed by the waters accordingly. As Hopkins (1992) notes, aquatic phenomena and lake-bursts were associated with death, creation and reorganization of land. Thus, both waters and lake-bursts were important geopolitical allies, but could also cause political havoc if the river courses changed or new waterbodies appeared. Theurkauf (20I7:80) also reminds us of how one of the Dindshenchas poems (Boand II, Gwynn ed. I99I[I9I3]:37) mentions the extramartial love relationship between Boand and the god Dagda, where Boand approached the well to wash away her sin. Hence, water was also made use of as an agent in sexual and body politics.

The place-lore poems collected above add another aspect for understanding rivers and water environments, namely, that they were alive with both benevolent and malevolent forces, and they had strong agentic powers. The example given in the story of Slán (and the other stories where waters were running through skulls or over bones), suggest that the conjunction of water and body parts brought a particular type of life and agentic power to each other. The transferral of a particular type of life, from water to object, was also carried out directly, as when water was flowing through and activated the skulls, attracting the particular characteristics of water from the underground/otherworld. There was a mutualism, where both water and deposition made otherworldly water come out into the world of the living.

\section{Personhood of waters}

As shown above, there is ample evidence in the written sources that these waters were considered as living beings, instead of inanimate materia. They were described as having body parts such as eyes, arms and legs, and as bodies of waters, capable of reciprocal and possibly transcorporeal sensing between human and more-than-human bodies. They were not passive re- 
ceivers of depositions, but reacted both benevolently and malevolently to these. Furthermore, these waters affected the thinking of people, supplying what we can call more-than-human wisdom, that of water, which inspired poets and informed their creative processes. These texts may be early accounts of how people were 'thinking through the environment' (see Rose et al. 20I2), where water, conceptualized in modernity as inert nature, at this earlier stage had such agency that it affected people's thoughts, exercising 'thing power', which accessed, intervened in and expanded the human mind. This reasoning could be discussed in relation to Braidotti's (20I3) neo-vitalism, and suggests that human awareness and consciousness were conditioned on cross-cutting alliances of both organic and inorganic processes, where engagement with the water element made a difference. These waters were not only ascribed meaning and perceived as living beings, but their agential powers were acknowledged in the poems and they worked as vital influencers in the world.

However, artefact depositions in watery places may also have contributed to the shaping of the personhood of these particular waters in more direct ways. Artefact depositions of items such as neck-rings, swords or cauldrons (artefacts which depend on local traditions) could also have worked both to address these waters as a person, but also as features that expanded the personality of the rivers and lakes. This can be exemplified with the story of Slán, where the artefacts and bones were placed in a well and related to the water as a king of water, and can be understood first as an observation of its existence and vitality, but secondly also as a way of paying tribute to the 'king of waters', or of the Shannon or Boyne rivers, where a range of different parties contributed to the assemblages that engendered such personhood. The depositions could then work as jewellery, adorning or decorating the waters, and as such they would work to expand and alter the personhood of rivers, lakes and wetlands.

It is worth noting that agency is, as Bennett (2010:9) puts it, 'distributed across a wider range of ontological types' in a way that 'draws attention to an efficacy of objects in excess of the human meanings, designs, or purposes they express or serve' (Bennett 2010:20). This means that the agentiality of deposited things, as well as the waters, can be recognized as producing effects that are beyond human intentionality and capture, but which possibly may be sensed as enchantments, hauntings or other presences in the landscape. Again, it is important here to note the difference between someone ascribing meaning to an object or environment, and the sensing, acknowledgement and observation that the waters are alive; that there is not only something there, but also someone, to receive the gifts.

The place-lore also shows how bodily presence (of the dead, dying bodies or body parts) at wells caused otherworldly waters to pour out into the world 
of the living, forming the river. To use Haraway's (2008:I6-I7) term 'becoming with', human and non-human subjects became something new in alliance with each other as more-than-human waters with agentic capacities, which co-worked with humans and thereby eventually made it into storytelling and place-lore. Here, both humans and animals transformed into what today would be classified as natural features (a river and a rock). However, another way of acknowledging this ontology is that the women and the dog Dabilla, and the otherworldly waters, merged and got reincarnated as new nature-culture phenomena, which is to say, they revitalized the waterways in the world of the living. It has long been argued that there was evidence for reincarnation in 'Celtic belief', where for example Piggott (I968:I20-I2I) summarized evidence about the Celts from classical sources such as Posidonius, which show that 'the souls of men are immortal, and that after a definite number of years they live a second life when the soul passes to another body', or Strabo writing that the soul was 'indestructible, although at times fire and water may prevail'. This is also found in a passage from De Bello Gallico (Edwards 1917:339, Book 6.I4), where souls were described as if passing from one person to another.

The transmigration of the soul through water is also known from other early Irish sources (see Bondarenko 20I3). An oft-cited example is both the birth of the hero Cú Chulainn, where one version suggests a transmission of the soul to his body through an intake of a small water bug (Hamel I933). Furthermore, in The Wooing of Étain, the young woman Étain is first transformed into a pool of water, which when warmed up and transformed into a worm, which made it into a purple fly, that after years passed, landed in a cup of water. That water and fly were then drunk by a woman who eventually conceived Étain as a human again (Gantz I98I:39-59).

Hence, the soul is described as able to merge not only with water as an element, but also to move between species and over time, suggesting an extensive ontology of how human-animal and nature relations were interlinked across multi-species generations. The place-lore that explains the names of these rivers could be taken to suggest that Sinnan, Boand and Dabilla were to some degree reincarnated in the waters. But it is unclear if these souls were acknowledged as fully human. Then the personhood of these rivers would be a multiplicity, a coming together of a range of different sources and forces where the placing of bodies and artefacts in them would have played a part. The depositions of body parts and artefacts may also have contributed to making the rivers such as the Shannon or Boyne (and lakes) into human and more-than-human conglomerates. However, the Shannon is no longer Sinnan, but more-than-Sinnan; and the Boyne is not Boand, but more-than-Boand. Hence, they became more than mere river or mere human, nature or culture, but their vitality and co-created 
personhood may have been observed and come into being as an entanglement of these, where the depositions had a significant role.

Lund (20IO) discusses how depositional objects were designated for otherworld creatures. The poems above add another, more immanent, type of explanation, that these waters and perhaps also the things themselves, were creatures that were alive, not only in a transcendent otherworld, but in the world of the living. They had a personhood that was enhanced, for example through the meeting with human and animal body parts, or which was decorated with depositions of objects such as jewellery or swords. Hence, one interpretative possibility is that the things deposited in waters were not only for deities in the otherworld, but for the more-than-human persons of rivers, lakes and wells which were also working in the world of the living.

\section{Things and tales through which to observe the world}

What I wish to explore here, and take one step further, is what would happen if we also looked at depositions of swords, skulls and so forth as apparatuses of observation which provide us with insights into ontologies of the past and as possible ways of intra-acting with waters. What I mean is that the placing of objects in water may assist us in gaining knowledge of how their world existed and came into being. Here I make use of Barad's (2007:90, I4I) reasoning that ontology, ethics and epistemology merge when one engages in knowledge production through the use of various apparatuses, and also co-constitute the world. Important in this agential realism are tools of observation, such as measuring equipment in a laboratory, theoretical concepts, but as I suggest here also poems. And as tested here, the deposition of things and bodies in waters, which may sharpen our ways of sensing the agencies of watery environments, while also assisting us in understanding how they co-create, and also diffract, the world in sometimes unexpected ways.

Seemingly, these poems contain information that resembles scientific knowledge about rivers and waterflows (see a similar argument in Hikuroa 20I7). The poem of the River Boyne describes how Segais rose to chase Bóand across the landscape, which made the water flow out over the land. It also disfigured her and took her life. The injuries, particularly those inflicted on Bóand, also correspond with those found on corpses left in water, where the face, hands and feet often erode first. As Haglund (1993) describes it, when a human body is placed in water it will normally sink to the bottom and remain there until putrefying gases work to increase the buoyancy of the body. This will cause the body to rise to the surface and float. When 
the body rises it floats face down, with the head lower than the rest of the body. During this process it may sustain injuries like abrasions on prominent parts of the face, the front parts of the legs and other extremities.

One possible interpretation is that the poems captured ontologies in which waters were alive, had wisdom, emotions, and possibly even worked as sacrificial agents when they came in contact with these bodies and consumed the victim. In a similar vein, as described by Bennett (2010), these rivers were 'vital players' in the world through their materializing actions. Here, the poem frames a particular aspect of the world, and the character of how waters intra-act with bodies to produce and accept what may be sacrifices.

Moreover, it has been noted by many researchers that depositions were structured according different types of waters and where, for example, objects understood as female have been associated with still waters and male with running waters, but where these principles were situated differently in various environments (e.g. Fontijn 2003; Yates \& Bradley 20Io; Fredengren 20II; Bradley 20I7). Here, this reasoning could also be taken one step further by Barad's theories to suggest that these depositions would have worked as apparatuses, where particular characteristics of water were acknowledged, but where connections between these and things or bodies were merged, stabilized and came together as a gendered phenomenon, merging into the making of some waterways female, others as male.

Above all, as argued above, such depositions can be understood as coworking to bring otherworldly waters into the world of the living. It can then be argued that such depositions were acknowledged as agentic in the creation of rivers and lakes in new places (think for example of how the River Boyne or Lough Key sprang out on the deaths of Cé or Boand); they made the world and the watery landscape come into being in new ways. The depositions therefore worked as a way of paying close attention to the living capacities and agencies of water, and thereby also bring out such particular qualities of the world, and make these ontologies come into being. They, through being apparatuses of observation, make certain parts of reality hyper-real, and also interact with the studied material. Hence, they could work to stabilize this aspect of the world and some of the active characteristics of water, while possibly at the same time diverting attention from other aspects of the lively ecologies of the water environment.

\section{You cannot step into the same river twice}

With this as a background it is possible to discuss how bodies of waters in north-western Europe might also have been recognized as persons where 
both the waters and depositions of bodies and artefacts would have worked to co-produce their personhood. Here, we need to underline the shift that takes place when we move from anthropocentric interpretations that take these stories as evidence for 'meanings ascribed to the landscape' or human perception of the landscape, to acknowledging that they, to some extent, are also ontologies that capture how the world comes into being and develops, where water contexts contribute agentically and react to what was placed in them or what was located in their ways, but also how such agencies influenced human storytelling and literature. However, as noted by Bennett (2010:5) things are never fully exhausted by semiotics; furthermore they have workings outside human contexts. Likewise, these bodies of water carry excessive connections which will reach far beyond what can be contained in storytelling, with relations that stretch onto land, into human and animal bodies alike.

There could be similarities with the Maori way of observing rivers (Hikuroa 20I7), but the paths along which these rivers were brought into existence are different from each other. Of course, these waters are situated in completely different locations on earth and would have very different histories. It is, however, important to note that depositions suggest that wetlands, lakes and rivers in North-western Europe may also have been observed as alive and agentic, not least as acknowledged through the varied and regionally-situated archaeological material of both things and depositions of body parts in watery places. However, the relations that brought these rivers into being changed over time. While the use of literary and other documentary sources support and enrich this interpretation, such use also runs the risk of erasing historical change as well as downplaying contemporary regional differences in ontologies, materialities and practices. There is, as discussed, some agreement between the sources in terms of characteristics, places and practices. The deposition of things and bodies in waters has been observed in the archaeological material across most of Europe, and seems to have been carried out for a considerable amount of time, while their compositions and more local placing changed (see Bradley 20I7, figure I). Hence, it is important to underline how the practices of deposition and sacrifice may be based on situated ontologies/epistemologies and performed within local practices of ecological knowledge. While making use of analogical reasoning and working in between the materiality and texts it is important to pay attention to these dissonances to avoid the pitfalls of freezing history to the time when a particular literary source was in use. It is important to move carefully between the different source materials and to treat the themes outlined in the literary studies with care and for inspiration, and to allow room for variation of the temporal and geographical kind that the archaeological material shows. 
This research acknowledges the complexities of using documentary sources and archaeology together, and has explored the nature/culture relationships which were brought into being through materialities, practices and stories connected to the deposition of human and animal remains and artefacts in water. While the literature discussed above clearly deals with issues primarily relating to human bodies, as well as to artefacts in the waters that are also found in the archaeological material, archaeological material instead has the potential to provide other information, such as how common the practice of depositing artefacts and human remains such as skulls was, the content and practices which surrounded such depositions, which sites were used or how the people were selected for sacrifice, how their bodies were treated and the extent to which the practice changed over time. These depositional practices and their uses in storytelling may have played a significant role in what could be termed a partial and local performance, and taking on a variety of relationships with, and observations of, waters. Instead the material shows a network of partial realities which seem to recycle common elements in local ways in the making of variously situated critical and sometimes cruel cartographies.

Further, the practice which resulted in the presence of both bodily remains as well as deposited artefacts may have had more direct material effects in later societies. The artefacts could have been retrieved and therefore could have worked as interventions in processes appearing at much later times, thereby re-minding, in a real sense, of earlier stories and being one of the causes of how a storytelling event may be started. The finds 'act up', so to speak, when they appear and demand an explanation. It is possible to say that the material culture creates a certain stability for the storytelling. However, the themes and variations come to us in hybrid forms. It is not possible, as Heraclitus famously stated, to step into the same river twice, however this does not mean that there are no similarities in how rivers are engendered through a range of more-than-human agencies and vitalities.

\section{To sharpen our ecological sensibilities}

To summarize, based on both the written sources and the depositions made in watery places, there are reasons to believe that the water environment was observed as alive, sentient and with a more-than-human personhood. The waters provide inspiration and affect poetry writing and storytelling; the element, so to say, speaks through the poets, who can capture their materializing powers. However, the excesses of water, and seeing eye to eye with water, may also be too much for what a human can handle. Waters as described in the literature also worked as sacrificial agents which choose 
and consumed life, but also transformed lifeforces into other formats. The place-lore informs of more fluid ways of drawing the boundary between life and death, and also between humans, animals and nature, transcendence and immanence. According to the stories, both skulls and artefacts contributed to eruptions of waters in the landscape or adorned it. Not only was there a mix between nature and culture, but the boundary between object and subject was merged, which in turn could have worked as a basis to legitimate or disturb various social arrangements, be they gender divisions, relationships to land or engagements with the water environment.

As discussed above, both poems and deposited things can be understood as situated apparatuses and tools to observe the world, and at the same time they provided a way to intra-act with the world that shaped the way it came into being. Furthermore, the deposition of both objects and bones can be understood as materialities which both acknowledged the personalities of waters and added to the personhood of these places, and which together with waters exerted more-than-human agency to the degree that they figured in poetry and storytelling.

What this implies is that new parts of reality may unfold through acknowledging shared human and non-human ontologies by engaging with, and paying close attention to, those that may have been classed separately as the environment or nature. However, as shown here, engaging with both archaeological things and places, as well as literary sources, may sharpen a different ecological sensibility in relation to waters, teasing out other ontologies and inviting us to pay much closer attention to these watery places, to improve our sensibility for these places. This, as Bennett (2010:I0) argues, is of great importance 'to experience the relationship between persons and materialities more horizontally', and in the context of the current paper, this may mean to alter the engagement with the water-environments in more responsive and responsible ways.

Ghosh (20I6:3, II, 64-65) calls the period we live in today the 'Great Derangement' and describes it as the 300 years or so when a significant number of humans believed that the planet was inert, resulting in the silencing of a variety of non-human forces around us. This belief hides the violent forces involved in economic exploitation and climate change as well as the deification of an idealised human. Some of the written accounts may anthropomorphize nature, which according to Bennett (20I0:Xvi, I8) is used as a tactical move to let in the agentialities of the non-human, rather than as way of seeing humans everywhere. While opening up for the agentialities of waters, there is a need to be alert to the gender and species politics involved in who gets projected as a naturalised other, as exemplified in some of the place lore about rivers. These texts have their historical/ political context and are not always innocent. My addition to this discus- 
sion through this paper, but also to the Environmental Humanities, may lie in an archaeology which contributes to scientifically informed ecological storytelling, in ways which encourage us to pay closer attention to the more-than-human environment - to respond to past, current and future states of affairs, and importantly to bring our critical faculties to ask questions about how ontologies, ethics and epistemologies are woven together and change over time - and to discuss what happens if we consider differently the boundary between life and death, mind and materia. Moreover, this research provides examples of how rivers, lakes and even wetlands, in the areas now called north-western Europe, may have been observed and treated as alive, with personhood, before the Great Derangement, when other ontologies of inert nature took precedence. The material presented in this paper shows water as a somewhat violent ally in the landscape, which from time to time co-works to carry out sacrifices of both human and nonhuman agents as well as of land masses. Hence, it points to knowledge from other times, which may be of importance for unlearning damaging beliefs and practices relating to waters, but also for paying respect to relations with a range of more-than-human others.

\section{Acknowledgements}

I would like to thank John Carey and Edel Bhreathnach for reading and commenting on parts of this text that were worked on in connection with the Lake Settlement project of the Discovery Programme. The text has since taken evolved and taken new routes. I am grateful to my anonymous referees for sharing their knowledge towards the improvement of this text, as well as to everyone else who has helped me along in my archaeological fieldwork by waters. Here, Sam Moore and Nathan Fredengren are thanked for company and careful surveying of 'the eye' on the lake bed of Lough na Súil, Co. Sligo.

\section{References}

Aitchison, N.B. 1996. Votive Deposition in Iron Age Ireland: An Early Medieval Account. Emania. Vol. I5 pp. 67-75.

Alaimo, S. \& Hekman, S. 2008. Introduction: Emerging Models of Materiality in Feminist Theory. In: Alaimo, S. \& Hekman, S. (eds). Material Feminism, pp. I-22. Bloomington: Indiana University Press.

Barad, K. 2007. Meeting the Universe Halfway. Durham: Duke University Press.

Barad, K. 20I 2. Nature's Queer Performativity. Kvinder, Kön \& Forskning. Vol. I-2 pp. $25-53$. 
Bennett, J. 20I0. Vibrant Matter: A Political Ecology of Things. Durham: Duke University Press.

Bieler, L. 1979. The Patrician Texts in the Book of Armagh. Scriptores Latini Hiberniae Io. Dublin: The Dublin Institute for Advanced Studies.

Bondarenko, G. 2013. The Migration of the Soul in De chophur in dá muccida and other Early Irish tales. In: Toner, G. \& Mac Mathúna, S. (eds). Ulidia 3. Proceedings of the Third international Conference on the Ulster Cycle of Tales, pp. I37-I47. Berlin: Curach Bhán Publications.

Bradley, R. I990. The Passage of Arms: An Archaeological Analysis of Prehistoric Hoards and Votive Deposits. Cambridge: Cambridge University Press.

Bradley, R. 20I7. A Geography of Offerings: Deposits of Valuables in the Landscapes of Ancient Europe. Oxford: Oxbow Books.

Braidotti, R. 2013. The Posthuman. Cambridge: Polity Press.

Breatnach, L. I98I. The Caldron of Poesy. Ériu. Vol. 32 pp. 45-93.

Carey, J. 2000[I983]. The Location of the Otherworld in Irish Tradition. In: Wooding, J.M. (ed.). The Otherworld Voyage in Early Irish Literature, pp. II3-I I9. Dublin: Four Courts Press.

Carey, J. 2004. The Names of the Plains Beneath the Lakes of Ireland. In: Carey, J., Herbert, M, \& Murray, K. (eds). Cín Chille Cúile - Texts, Saints and Places: Essays in Honour of Pádraig Ó Riain, pp. 44-57. Aberystwyth: Celtic Studies Publications.

Doherty, C. 2005 . Kingship in Early Ireland. In: Bhreathnach, E. (ed.). The Kingship and Landscape of Tara, pp. 3-3I. Dublin: Four Courts Press for the Discovery Programme.

Downey, C. 2010. Dindshenchas and the Tech Midchúarta. Ériu. Vol. 60 pp. I-35.

eDIL: Electronic Dictionary of the Irish Language. nd. Concise edition. http://www.dil.ie. [Accessed 26 April 20I9].

Edwards, H.J. translated. I9I7. Caesar. The Gallic War. Loeber Classical Library 72. Cambridge (MA): Harvard University Press.

Fontijn, D. 2003. Sacrificial Landscapes: Cultural Biographies of Persons, Objects and 'Natural Places' in the Bronze Age of the Southern Netherlands c. 2500-600 BC. Analecta Praehistorica Leidensia. Vol. 33-34.

Fowler, C. 2004. The Archaeology of Personhood: An Anthropological Approach. London: Routledge.

Fredengren, C. 2002. Crannogs: A Study of People's Interactions with Lakes, with Particular Reference to Lough Gara in the North West of Ireland. Bray: Wordwell.

Fredengren, C. 20I . Where Wandering Water Gushes: The Depositional Landscape of the Mälaren Valley in Late Bronze Age and Earliest Iron Age of Scandinavia. Journal of Wetland Archaeology. Vol. Io pp. I09-I35.

Fredengren, C. 2015. Water Politics: Wetland Deposition of Human and Animal Remains in Uppland, Sweden. Fornvännen. Vol. II I pp. I6I-I83.

Fredengren, C. 20I6. Unexpected encounters with Deep Time Enchantment: Bog Bodies, Crannogs and other Worldly Sites at Disjuncture's in Time. Archaeology and Environmental Ethics. World Archaeology. Vol. 48(4) pp. 482-499.

Gantz, J. I98I. The Wooing of Étaíne. In: Early Irish Myths and Sagas, pp. 39-59. Translated by Gantz. London: Penguin.

Ghosh, A. 20I6. The Great Derangement: Climate Change and the Unthinkable. Chicago: The University of Chicago Press. 
Gray, E.A. (ed.) 1982. Cath Maige Tuired: The Second Battle of Mag Tuired. Irish Texts Society. No. 52. Kildare: Irish Texts Society.

Grogan, E., O'Donnell, E. \& Johnston, P. 2007. The Bronze Age Landscapes of the Pipeline to the West. Bray: Wordwell.

Gwynn, E. (ed.) I99I[1906]. The Metrical Dindshenchas. Volume 4. Dublin: Dublin Institute for Advanced Studies.

Gwynn, E. (ed.) I99I[I9I3]. The Metrical Dindshenchas. Volume 3. Dublin: Dublin Institute for Advanced Studies.

Haglund, W.D. I993. Disappearance of Soft Tissue and the Disarticulation of Human Remains from Aqueous Environments. Journal of Forensic Science. Vol. 38 pp. 806-8I 5 .

Hamel, A.G.v. I933. Compert Con Culainn and other Stories. Medieval and Modern Irish Series G. Dublin: Dublin Institute for Advanced Studies.

Haraway, D. 2008. When Species Meet. Posthumanities Volume 3. Minnesota: University of Minnesota Press.

Haraway, D. 2016. Staying with the Trouble: Making Kin in the Chthulucene. Durham: Duke University Press.

Hedeager, L. 20Ir. Iron Age Myth and Materiality: An Archaeology of Scandinavia AD 400-IO00. London: Routledge.

Holbraad, M. \& Pedersen, M.A. 2017. The Ontological Turn: An Anthropological Exposition. Cambridge: Cambridge University Press.

Hikuroa, D. 20I7. Mātauranga Māori-the ūkaipō of Knowledge in New Zealand, Journal of the Royal Society of New Zealand. 47(I) pp. 5-10.

Hogan, E. I910. Onomasticon Goedelicum. Dublin: Hodges \& Figgis.

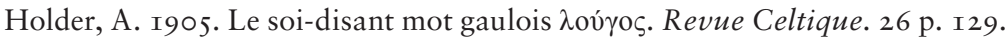

Hopkins, P. I992. The Symbology of Water in Irish Pseudo-History. Proceedings of the Harvard Celtic Colloquium. Vol. I2 pp. 80-86.

Joyce, P.W. I875. Irish Names and Places. Vol. 2. Dublin: McGlashan \& Gill.

Leonard Jones, H. translated I923. Strabo. Geography, Volume II: Books 3-5. Loeb Classical Library 50. Cambridge (MA): Harvard University Press.

Lund, J. 20Io. At the Water's Edge. In: Carver, M., Sanmark, A. \& Semple, S. (eds). Signals of Belief in Early England: Anglo-Saxon Paganism Revisited. Oxbow Books: Oxford and Oakville.

Lund, J. 20I7. Connectedness with Things: Animated Objects of Viking Age Scandinavia and Early Medieval Europe. Archaeological Dialogues. Vol. 24(I) pp. 89-Io8.

Muhr, K. I999. Water Imagery in Early Irish. Celtica. Vol. 23 pp. I93-210.

National Monuments Service. The Sites and Monuments Database. nd. Historic Environment Viewer. Department of Arts, Heritage and the Gaeltacht. http://webgis.archaeology.ie/historicenvironment/. [Accessed 26 April 20I9].

Ó Concheanainn, T. I98I. The Three Forms of Dindsenchas Érenn, Journal of Celtic Studies. Vol. 3 pp. 88-гзI.

O'Grady, S.H. I857. The Pursuit after Diarmuid O'Duibhne, and Grainne the Daughter of Cormac Mac Airt. Dublin: The Ossianic Society.

Piggot, S. 1968. The Druids. London: Thames and Hudson.

Price, N. 20I0. Passing into Poetry: Viking-Age Mortuary Drama and the Origins of Norse Mythology. Medieval Archaeology. Vol. 54(I) pp. I23-I56. 
Rose, D.B., van Dooren, T., Chrulew, M., Cooke, S., Kearnes, M. \& Gorman, E. 20 I2. Thinking through the Environment, Unsettling the Humanities. Environmental Humanities. Vol. I pp. I-5.

Ross, A. I962. Severed Heads in Wells: An Aspect of the Well Cult. Scottish Studies. Vol. 6(I) pp. $3 \mathrm{I}-48$.

Ross, A. I996[1967]. Pagan Celtic Britain. Chicago: Academy Chicago Publishers.

Ruru, J. 20I8. Listening to Papatūānuku: A Call to Reform Water Law. Journal of the Royal Society of New Zealand. Vol. 48(2-3) pp. 215-224.

Simpson, J. 1962. Mimir: Two Myths or One. Saga-Book 16. London: Viking Society for Northern Research, University College.

Stokes, W. I892. The Bodleian Dinnshenchas. Folklore. Vol. 4 pp. 467-5I6.

Stokes, W. 1905. The Colloquy of the Two Sages. Revue Celtique. Vol. 26 pp. 4-285.

Theuerkauf, M.-L. 20I7. The Death of Boand and the Recensions of Dindsenchas Érenn. Ériu. Vol. 67 pp. 49-97.

Thurneysen, R. I92 I. Die Irische Helden- und Königsage bis zum Siebzehnten Jahrhudert. Halle: Niemeyer.

Waddell, J. 20I4. Archaeology and Celtic Myth: An Exploration. Dublin: Four Courts Press.

Yates, D. \& Bradley, R. 20Io. Still Water, Hidden Depths: The Depositions of Bronze Age Metalwork in the English Fenland. Antiquity. Vol. 84 pp. 405-4I5. 